INTERNATIONAL JOURNAL OF
ORGANIZATIONAL LEADERSHIP
ORGAANZATIONAL
LEADESHIP

\title{
The Effect of Servant and Transformational Leadership Styles on Employee Creative Behavior: The Moderating Role of Authentic Leadership
}

\author{
Ahmet Cengiz Ucar ${ }^{1 *}$, Lutfihak Alpkan ${ }^{2}$, and Meral Elci ${ }^{3}$ \\ ${ }^{1,3}$ Department of Management, Gebze Technical University, Kocaeli, Turkey \\ ${ }^{2}$ Department of Management, Istanbul Technical University, Istanbul, Turkey
}

\section{Keywords: \\ Creative Behavior, Servant, \\ Transformational and \\ Authentic Leadership}

\section{Received}

29 June 2021

Received in revised form

20 July 2021

Accepted

23 July 2021

*Correspondence:

acucar@gmail.com

\begin{abstract}
Leaders are expected to trigger and increase the creative behavior of their followers, and hence they need to adopt various leaderships together. This study focuses on the effect of the servant and transformational leadership on employee creative behavior and the moderating role of authentic leadership on these relationships. One thousand one hundred forty-six blue- and white-collar employees working in the western region of Turkey were selected by convenience sampling. Confirmatory factor analysis (CFA) and Process Macro by Hayes have been used to determine the effects and interactions among variables. Servant and transformational leadership were positively related to employee creative behavior, and that these effects increased if moderated by authentic leadership. Thus, authentic leadership strengthens the positive impact of servant and transformational leadership on employee creative behavior. It is predicted that leaders should be servants or transformational leaders to increase employee creative behavior in their organizations. It should be taken into account that if these leaders also exhibit authentic leadership, the effect of leadership on employee creative behavior will be even greater. A second leadership is also included in the relationship between leadership and employee creative behavior, which is generally examined through a single leadership type. The interaction of this second leadership with other leadership is also tested.
\end{abstract}

Employee creative behavior has become an important issue that can not be ignored in recent years. Both employers and academics emphasize this behavior very often and strongly in their 
own atmosphere. Creative behavior can be explained based on creativity because one is ideabased, and the other is related to turning this idea into behavior, so creativity and creative behavior should also be discussed together. Creativity is briefly defined by Amabile (1988) and Zhou and Shalley (2011) as revealing new and effective ideas on products, processes, and procedures. It is also accepted that today creativity is a job requirement for employees (Unsworth, 2001). In addition, making suggestions to improve one's own workflow and developing new and useful ideas to solve problems to overcome difficulties can also be described as a creative process. For these reasons, it is now a necessity for companies to support creativity and creative behavior to achieve their goals and gain competitive advantages against competitors (Amabile, 1988). Many studies have focused on the individual's cognitive orientation and intrinsic motivation to increase creativity (Amabile, 1988; Woodman et al., 1993), but later other researchers have focused on collaborations (Bullinger et al., 2004), group interactions (Rickards, Chen, \& Moger, 2001) and showed that surroundings also influence creativity and innovation, such as leadership (Amabile et al., 2004) and organizational hierarchy (Artz et al., 2010; Damanpour, 1996).

Transformational leadership is one of the most dominant paradigms in the relationship between creativity and leadership (Bono \& Judge, 2004). With this leadership, it is hoped that the values and attitudes of the employees will be aligned with the organization and the employees will show performances beyond expectations (Bass \& Riggio, 2005; Çömez et al., 2011). In addition, transformational leaders strive to create a periphery where different ideas are valuable (Jung et al., 2003) and agree to be a role model that encourages opposite ideas and comments (Howell \& Higgins, 1990). This creates a climate where creativity is affirmed (Kearney \& Gebert, 2009). This type of leadership has been shown to be associated with many positive work behaviors, including well-being, task performance, and creative behavior (Piccolo \& Colquitt, 2006; Shin \& Zhou, 2003).

While leader approval is required to use power and the realization of activities in traditional leadership, power-sharing is the priority in servant leadership. The servant-leader stands themself back and focuses primarily on the needs of the employees. Wong and Page (2003b) stated that this leadership takes the first place among other leaderships in achieving the common good and goals and ensuring employee development. This leadership also includes a perspective that values people and pushes them to act authentically (Laub, 1999). Russell and Stone (2002) mentioned empowerment, ability development, teaching, authorization, and encouragement while listing the characteristics of servant leadership. It is clear that this type of leadership, which supports authenticity and employee development, has a positive relationship with positive work behavior.

The importance of authentic leadership has increased due to the need for reliable and transparent leadership (Avolio \& Gardner, 2005). According to Neff and Harter (2002), authentic leadership is described shortly as being honest with oneself, but it is known that there are other factors rather than honesty, such as self-confidence and optimism (Arda et al., 2016; Ilies, Morgeson, \& Nargang, 2005; Shamir \& Eilam, 2005). This type of leader is consistent with what they say and what they do (Simons, 2002). Walumbwa et al. (2008) stated that authentic leadership has a better relationship with organizational citizenship behavior, organizational commitment, satisfaction, and individual job performance than other 
leaderships. Employees also feel psychologically secure with these leaders and seek creative ways to solve problems and use opportunities (Prati et al., 2003).

In this study, employee's perception of leadership is placed at the center of employee's creative behavior, so this study will also have a role in examining employee perceptions, attitudes, and intentions that affect employee creative behavior. Few studies in the literature consider leaderships together, but the effects of a single leadership on employee behavior have been frequently studied. Therefore, while examining the effect of the servant and transformational leadership on creative behavior, we also focused on the role of authentic leadership. Although the effect of all three leaderships on creative behavior is positive, it has been shown by testing that authentic leadership also has a positive moderator role on other leaderships. This study first begins with the presentation of the theories supporting the models, continues with the development of hypotheses, and concludes with the methodology, results, discussions, and ends with the conclusion.

\section{Theoretical Background}

According to Torrance (1993), creativity is considered a process in which employees show sensitivity to problems and make suggestions and activities to solve them. Since creativity is an uninterrupted process that solves organizational problems and enables the organization to achieve its goals (Amabile et al., 2005), it is accepted as a necessity for the industry.

Creative behavior, on the other hand, is a new phenomenon that has been studied recently in both individual and organizational fields. For example, George and Zhou (2001), who examined creative behavior individually, showed that creativity returns to the organization as creative behavior when supported by the organization. Accordingly, some factors affect this behavior in organizational terms (Amabile \& Gryskiewicz, 1989; Anderson, De Dreu, \& Nijstad, 2004), such as group support, organizational encouragement, autonomy, and sufficient resources (Amabile \& Conti, 1999; Amabile et al., 1996; Amabile \& Grykiewicz, 1989) to turn creativity into creative behaviors. Bain, Mann, and Pirola-Merlo (2001) and Burningham and West (1995) also pointed to the importance of organizational support, challenging goals, and task orientation in creativity. Among such organizational factors, leadership seems to be an important key to encourage the creativity of employees (Scott \& Bruce, 1994; Tierney et al., 1999).

One of the theories that state the leadership as an organizational factor impacts employee creative behavior is Amabile's componential theory of creativity (1988). Here, the influence of leadership on creative behavior is emphasized as a controlling incentive. With the support and intrinsic motivation provided by the leader, the creativity of the employees might increase. Setting goals, supporting the group, establishing effective communication within the group, showing confidence, and being open to new ideas also support creativity development (Amabile, 1997).

Bandura (2001) suggested that the basis of social learning theory is learning based on observing and imitating the behavior of others. Bandura (2001) also stated that social learning occurs from the reactions given and the observation of role models. In the leadership framework, this theory suggests that employees can learn by modeling the leader, that is, leaders influence their employees as a positive role model to act positively. In this respect, the most important factor of the social environment is the leader (Hannah, Avolio, \& Walumbwa, 2011). 
In the theory of planned behavior, Ajzen et al. (1991) and Rosenthal (2018) explained the relationship between perception, attitude, and behavior and stated that attitude and intention must be formed before the behavior occurs. It is seen that strong attitudes turn into behaviors over time (Fishbein \& Ajzen, 2005). Positive perceptions and attitudes are associated with positive behaviors, and negative perceptions and attitudes are associated with negative behaviors (Gonzalez et al., 2012).

Blau (1964) stated in his social exchange theory, an employee who receives positive reactions from their organization gives positive reactions mutually. For example, an individual supported by the organization engages in positive behaviors such as working hard and thinking extra about problems. This relationship between the organization and the individual is dynamic (Mearns \& Reader, 2008; Saks, 2006).

According to Amabile's componential theory of creativity, Bandura's social learning theory, Ajzen's planned behavior theory, and Blau's social exchange theory, we suggest that servant and transformational leadership directly affects creative behavior. If these two leaderships additionally exhibit authentic leadership in the organization, employee creative behavior increases.

\section{Hypothesis Development Servant Leadership and Creative Behavior}

Servant leadership is a leadership concept that acts in the direction of not gathering power in one man but sharing power. It serves the development of others by keeping the needs of others ahead of their own (Greenleaf, 2008). Laub (1999), on the other hand, defined servant leadership as a concept that values people, develops them and pushes them to act authentically. Russell and Stone (2002) listed some features such as being a role model, articulating a vision, having credibility, and empowerment to define servant leadership.

Many researchers have tried to determine the servant leadership dimensions, but recently, the dimensions determined by Van Dierendonck and Nuijten (2011) are empowerment, standing back, courage, forgiveness, humility, accountability, and responsibility.

Encouraging and empowering employees can be creative by providing intrinsic motivation (Neubert et al., 2016). Servant leadership is also related positively to organizational citizenship behaviors (Ehrhart, 2004; Walumba et al., 2010) and performance (Chiniara \& Bentein, 2016; Hunter \& Nielsen, 2013). These servant leaders we described above increase the possibility of using creative methods to solve problems (Liden et al., 2014; Yoshida et al., 2014). Servant leadership is also known to positively affect employee creativity due to its altruistic tendencies (Neubert et al., 2008). It has been argued that this leadership creates psychologically safe workplaces in which followers are inspired to take risks and develop new ways of working (Schaubroeck et al., 2011). Van Dierendonck and Nuijten (2011) also stated that servant leadership is the dominant leadership among others to create psychologically secure spaces that lead to positive follower behavior.

Because of the human-centered nature of the servant leader, the followers also feel that they are taken care of (Eva et al., 2019), and they respond to it by revealing their best performance, as Blau (1964) stated in his social exchange theory. Responses that followers can offer their leaders can include improving business processes as well as developing new ideas. Servant leaders' interest in supporting, empowering, and satifying his/her followers' needs (Yang et al., 
2017) also creates psychological trust among followers (Zou et al., 2015). This safe working environment created by the servant leader allows the followers to interact with the leader (Colquett et al., 2007) socially. In response to these behaviors of the leader, the followers also engage in creative behavior.

\section{Hypothesis 1: Servant leadership is positively related to creative behavior}

\section{Transformational Leadership and Creative Behavior}

A transformational leader makes an effort beyond expectations by motivating their followers and reflects this on the team and the organization (Bass \& Avolio, 1990). The leader initially focuses on intellectual effort and influences the attitudes and assumptions of the team (Bass \& Avolio, 1994). They want employees not to be stuck to the status quo and show that different ideas are valuable (Jung et al., 2003). They lead to diversity by exhibiting unexpected and creative behavior and sees it appropriate to encourage cognitive opposition (Howell \& Higgins, 1990), thus creating a climate in which different opinions are supported (Kearney \& Gebert, 2009).

Transformational leadership has been examined in four dimensions: charisma, inspirational motivation, intellectual stimulation, and individual consideration (Avolio \& Bass, 1995). These leadership dimensions are expected to increase the positive behaviors of employees within the organization. Transformational leadership positively affects creative behavior because the leader provides intellectual stimulation that shows followers creative thinking (Waldman \& Bass, 1991). Moreover, it is assumed that these leaders encourage their followers to adopt an inquiring and open mindset (Jung et al., 2003), thus producing original and creative ideas and solutions (Avolio, Bass, \& Jung, 1999). According to the social learning theory (Bandura, 2001), followers are expected to imitate the leader and engage in creative behavior. The leader is also the trainer of their followers, and the leader who is involved in intellectual stimulation also expects creativity from their employees. The leader, who is also a role model of employees, thus enables them to participate and learn (Bass \& Avolio, 1990). Since transformational leader also increases the self-efficacy of the employees (Pillai \& Williams, 2004), they still desire to change the status quo (Conger \& Kanungo, 1998; Shamir, House, \& Arthur, 1993). The inspirational motivation dimension supports the process of generating ideas in line with the vision of the organization. Inspirational motivation, which is increased due to the behavior of the transformational leader, is a source of creativity (Tierney et al., 1999). Amabile (1983) also stated that creativity occurs with intrinsic motivation. For this reason, inspirational motivation is considered as a dimension that increases creativity, such as intellectual stimulation. Based on the theories, we think that transformational leadership increases creative behavior, and the leader has an important role in displaying the creative behavior of followers.

\section{Hypothesis 2: Transformational leadership is positively related to creative behavior.}

\section{The Moderating Role of Authentic Leadership}

While Neff and Harter (2002) defined authenticity as feelings, thoughts, wishes, and beliefs that do not contradict one's self, Kernis and Goldman (2006) stated that stable and high selfesteem occurs in authentic individuals and that defensive, fragile and inconsistent self is not seen. Erickson (1995) stated that there is no such thing as completely authentic or not authentic at all. If the authentic individual is in a leadership position, leadership characteristics are 
generally explained in four dimensions; self-awareness, balanced processing, internalized moral perspective, and relational transparency (Walumbwa et al., 2008). An authentic individual who is in a leadership position does not change their attitudes and behaviors. It has been shown that an authentic individual does not behave like a traditional leader when they are a leader and that they conduct this leadership function only on expressing themselves and does not compromise on transparency and honesty (Gardner et al., 2005). The authentic leader also inspires employees with encouragement and enthusiasm using emotional experiences such as hope and optimism (Ilies et al., 2005; Zhou \& George, 2003). This inspiration broadens employees' perspectives and increases the probability of taking creative and innovative actions (Fredrickson, 2001). Authentic leadership also increases the leader-member exchange level, creates a sense of trust and freedom to fearlessly revealing conflicting ideas among employees, and enables followers to take responsibility easily (Avolio \& Gardner, 2005). People who work with authentic leaders are also more competent because the leader positively influences the values and behaviors of followers, ethically and spiritually (Laschinger et al., 2013). The authenticity of the servant leader can be understood as the leader's sincerity towards themselves and the harmony with the followers through ethical and spiritual values. This harmony creates dynamism, job involvement, job satisfaction, and trust in employees (Bobbio et al., 2012; Sendjaya \& Pekerti, 2010). Needless to say that ethics is a construct that theorists prioritize while defining servant leadership (Jaramillo et al., 2009; Liden et al., 2014; Sendjaya et al., 2008). The authentic servant leader focuses on moral consistency and concern about others. Concern for followers is about leaders' focus on defending and protecting their followers' interests. Servant leadership with authentic leadership behaviors supports the personal development of followers much more than expected. These behaviors encourage followers by establishing autonomy and self-efficacy that increase their pride and personal responsibility for work. Therefore followers encounter more moral and ethical behaviors, increase their personal development, and thus have more opportunities to get ideas to realize them (Lemoine et al., 2019).

It should be known that authentic leadership differs from servant leadership in what they focus on. For example, a servant leader focuses on the interests of stakeholders, while an authentic leader focuses on ethical values. Based on the recent studies, we state that authentic leadership differs from servant leadership, but it strengthens the relationship between servant leadership and employee creative behavior (Figure 1).

Hypothesis 3: Authentic leadership positively moderates the relationship between servant leadership and creative behavior. 


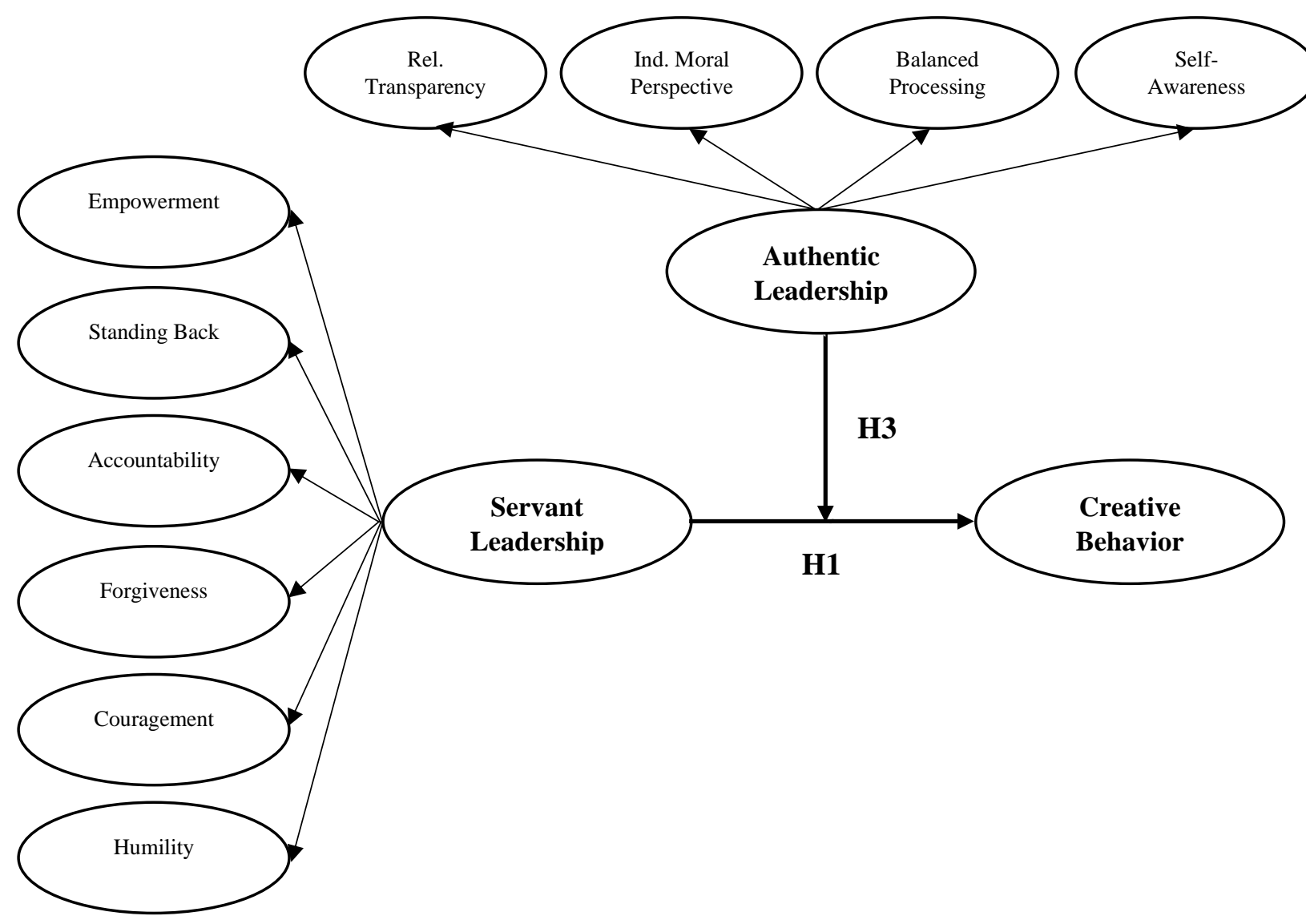

Figure 1. Theoretical model of Hypothesis 1 and Hypothesis 3

In addition to transforming their followers and organization, transformational leaders instill moral and ethical values: being authentic in their followers and enabling their followers to be productive for others (Zhu et al., 2011). Authenticity also provides the transformational leader with feelings of kindness, altruism, sincerity, harmony, trust, accountability, equality, and justice. It is stated that transformational leadership rises morally with the inclusion of authentic values in the leadership process (Burns, 1978). Dongil Jung and Sosik (2006) also argued that morally accepted courage and harmony make transformational leadership behavior authentic.

The four dimensions of transformational leadership now include a moral perspective, and this authentic transformational leader appears to be a moral person. Here, the transformational leader's being truly transformational depends on knowing what is good and bad, transforming the followers to themselves, developing their moral maturity, and wanting better for the group and organization other than themselves. Thus, apart from the characteristics of transformational leadership, the authentic transformational leader also can judge fairly and deals with group members morally.

Although it is evident that there is a positive relationship between authentic leadership and transformational leadership, a clear distinction between the two in terms of focus is also present, as in servant leadership (Walumbwa et al., 2008). With the authenticity of transformational leadership, followers find moral and fair workplaces, work more in harmony, are supported within the group, and thus have more opportunities to turn their ideas into reality (Prati et al., 
2003). Based on these studies, we would like to present that authentic leadership strengthens the relationship between transformational leadership and employee creative behavior (Figure 2).

Hypothesis 4: Authentic leadership positively moderates the relationship between transformational leadership and creative behavior.

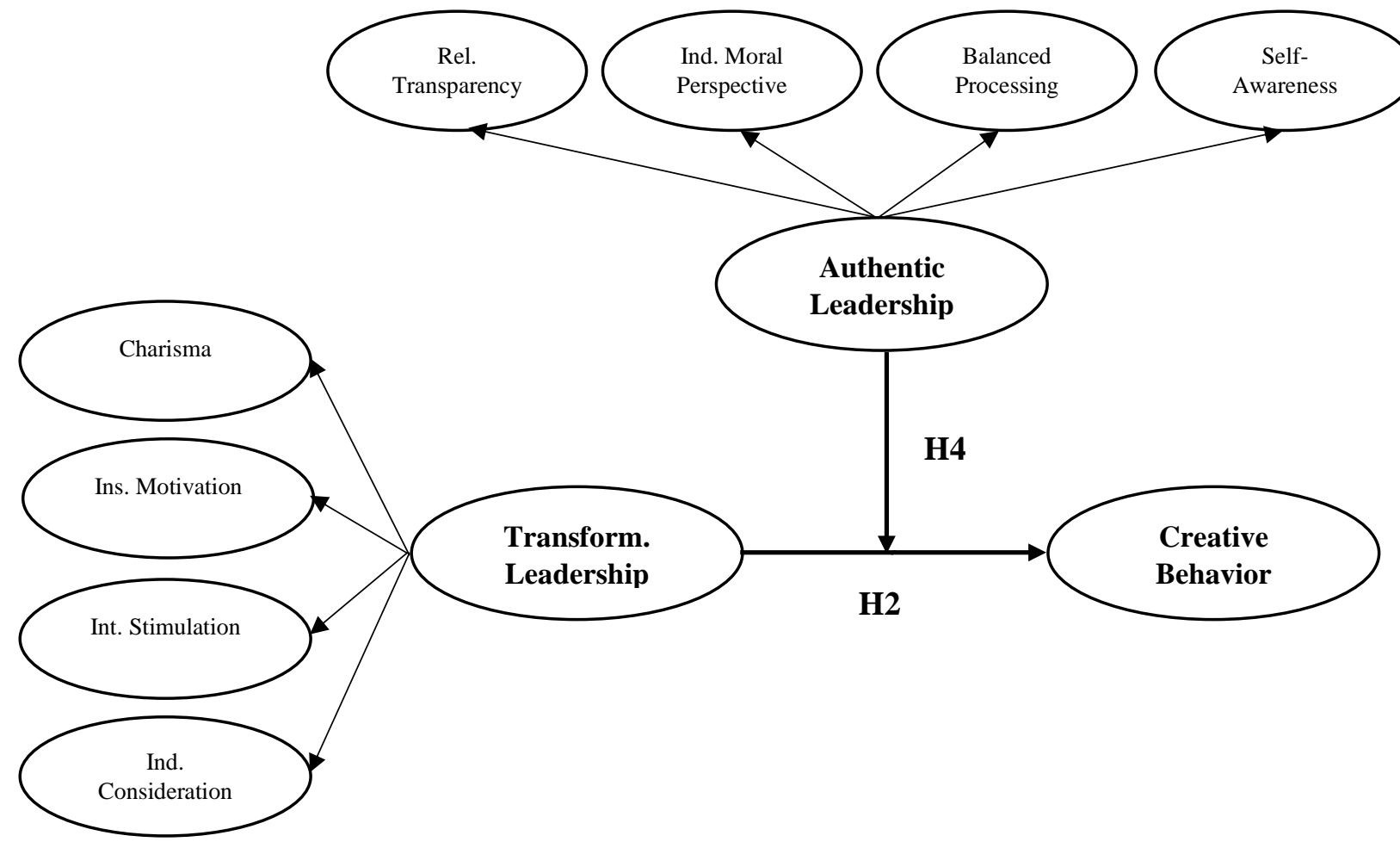

Figure 2. Theoretical model of Hypothesis 2 and Hypothesis 4.

Based on mentioned theories, followers are influenced by, aspire, and learn from their leaders. Therefore, the followers will respond positively to the leaders because these leaders serve or transform and show ethical values. As a result, positive individual and organizational outcomes are achieved. Furthermore, if servant and transformational leaders exhibit authentic leadership, they will positively increase employee creative behavior (Giallonardo et al., 2010).

\section{Method}

\section{Participants and Data Collection}

One thousand one hundred forty-six blue- and white-collar employees working in the western region of Turkey were selected by convenience sampling, and a cross-sectional questionnaire was applied. One hundred sixty-seven participant questionnaires were excluded from the analysis because most of the items in the questionnaire were not filled out. Mahalanobis distance, a multivariate outlier detection technique (Leys et al., 2018), was preferred to detect extreme values. Totaly, 119 cases were found as outliers and excluded from the analysis. Finally, 860 cases were used (the completion rate is $75 \%$ ).

$478(55.6 \%)$ of the participants who filled out the questionnaire were men, and 336 participants (39.1\%) were women. There is also a small number of participants who did not specify their gender. The rate of those who had bachelor's and master's degree is $79.9 \%$. The 
ages of all participants vary between 18 and 55, but the average age of participants was 32 years. In addition, the average tenure of the participants in the organizations is calculated as ten years, with approximately one-third of the participants working in manufacturing (305), onethird in the service (265), and the rest in other sectors (290). Care was taken to ensure the privacy of the participants to eliminate social desirability or acquiescence bias, and it was insistently emphasized that there were no right or wrong answers (Spector, 2006). Participants filled in the questionnaire by first completing the servant leadership scale, then the transformational leadership and authentic leadership scale, and finally the creative behavior scale. Demographical questions were placed at the end of the questionnaire as usual. This demographical information shows that the selected sample is suitable for conducting a reliable study.

\section{Measures}

The items were adapted from related questionnaires and validated by various papers. For leadership questionnaires, 1: Never, 2: Rarely, 3: Sometimes 4: Often and 5: Always (if not always, extremely often) and for creative behavior questionnaire, 1: Strongly Disagree, 2: Disagree, 3: Neither agree nor disagree, 4: Agree, 5: Strongly Agree, 5-point Likert scales were preferred.

Creative Behavior $(C B)$ : The first five items of this questionnaire were developed by George and Zhou (2001) and Tierney, Farmer, and Graen (1999), while the remaining three items were adapted into the Turkish language from various organizational creativity questionnaires.

Transformational Leadership (TL): Avolio and Bass' (2004) transformational leadership questionnaire has been confirmed and adapted to the Turkish language by researchers. The questionnaire contains 17 items and four factors. Of these factors, charisma is represented by seven items, inspiring motivation by four items, intellectual stimulation by three items, and three items present individual consideration.

Servant Leadership (SL): Van Dierendonck and Nuijten's (2011) servant leadership questionnaire is a frequently used and a validated questionnaire in the literature. The questionnaire was adapted to the Turkish language by researchers and consists of 23 items and six factors. Among these factors, empowerment is represented by seven items, standing back by three items, accountability by three items, forgiveness by three items, encouragement by two items, and humility is represented by five items.

Authentic Leadership (AL): Walumbwa, Avolio, and Gardner's (2008) authentic leadership questionnaire has been validated and carefully adapted to the Turkish language. The questionnaire consists of 16 items and four factors. Relational transparency is represented by five items, internalized moral perspective by four items, balanced processing by three items, and self-awareness is represented by four items.

\section{Measurement Model}

This study uses Confirmatory factor analysis (CFA) and Process Macro for hypotheses tests. Process Macro works efficiently when the model involves several structural path relationships (Hayes, 2018). This study aims to explore new relationships among variables that have been theoretically less studied or not studied at all. In addition, this study has second-order constructs and contains a moderator variable that makes the models more complex. 
Before performing CFA analysis, we explored data distribution by understanding Skewness and Kurtosis for each construct included in the models. All values for Skewness range from -.85 to -.18 , and all values for Kurtosis vary between -.61 and .80, which are below the threshold of \pm 1.50 for normality assumption (Tabachnick \& Fidell, 2013). This information tells us that our dataset is almost normally distributed. We also examined the reliability and validity of the first-order measurement model. Table 1 shows the item loadings, the Cronbach's alpha, the composite reliability (CR) scores used to assess indicators, and internal consistency reliability (Elrehail et al., 2018).

Table 1

The Reliability and Validity of Items and Constructs

\begin{tabular}{|c|c|c|c|c|c|c|}
\hline Construct & Dimensions & Cronbach's alpha & $\mathrm{CR}$ & AVE & Items & Loading \\
\hline \multirow{23}{*}{ SL } & \multirow{7}{*}{ Empowerment } & \multirow{7}{*}{.93} & \multirow{7}{*}{.91} & \multirow{7}{*}{.67} & Emp1 & .77 \\
\hline & & & & & Emp2 & .88 \\
\hline & & & & & Emp3 & .90 \\
\hline & & & & & Emp4 & .86 \\
\hline & & & & & Emp5 & .76 \\
\hline & & & & & Emp6 & .69 \\
\hline & & & & & Emp7 & .85 \\
\hline & \multirow{3}{*}{ Standing Back } & \multirow{3}{*}{.89} & \multirow{3}{*}{.86} & \multirow{3}{*}{.73} & StaBac1 & .87 \\
\hline & & & & & StaBac2 & .79 \\
\hline & & & & & StaBac3 & .89 \\
\hline & \multirow{3}{*}{ Accountability } & \multirow{3}{*}{.86} & \multirow{3}{*}{.81} & \multirow{3}{*}{.68} & Acc1 & .83 \\
\hline & & & & & Acc2 & .83 \\
\hline & & & & & Acc3 & .79 \\
\hline & \multirow{3}{*}{ Forgiveness } & \multirow{3}{*}{.80} & \multirow{3}{*}{.71} & \multirow{3}{*}{.58} & For1 & .74 \\
\hline & & & & & For2 & .75 \\
\hline & & & & & For3 & .78 \\
\hline & \multirow{2}{*}{ Couragement } & \multirow{2}{*}{.89} & 88 & & Cou1 & .90 \\
\hline & & & .88 & .81 & Cou2 & .90 \\
\hline & & & & & Hum1 & .85 \\
\hline & & & & & Hum2 & .84 \\
\hline & Humility & .93 & .90 & .72 & Hum3 & .81 \\
\hline & & & & & Hum4 & .85 \\
\hline & & & & & Hum5 & .89 \\
\hline & & & & & Cha2 & .80 \\
\hline & & & & & Cha3 & .75 \\
\hline & Charisma & 92 & 89 & 67 & Cha4 & .78 \\
\hline & Cranssina & .92 & .09 & .01 & Cha5 & .88 \\
\hline & & & & & Cha6 & .79 \\
\hline & & & & & Cha7 & .88 \\
\hline & & & & & InsMot1 & .78 \\
\hline TL & Ins Motivation & 91 & 88 & 72 & InsMot2 & .87 \\
\hline 10 & IIIs. Fivtivation & .51 & .00 & .12 & InsMot3 & .88 \\
\hline & & & & & InsMot4 & .86 \\
\hline & & & & & IntSti1 & .90 \\
\hline & Int. Stimulation & .92 & .91 & .82 & IntSti2 & .91 \\
\hline & & & & & IntSti3 & .90 \\
\hline & & & & & IndCon1 & .88 \\
\hline & Ind. Consideration & .90 & .89 & .78 & IndCon2 & .82 \\
\hline & & & & & IndCon3 & .94 \\
\hline & & & & & RelTra1 & .77 \\
\hline & & & & & RelTra2 & .81 \\
\hline & Rel. Transparency & .91 & .87 & .66 & RelTra3 & .83 \\
\hline & & & & & RelTra4 & .84 \\
\hline & & & & & RelTra5 & .82 \\
\hline & & & & & IndMor1 & .87 \\
\hline $\mathrm{AL}$ & Ind Moral Pers & 88 & 82 & 65 & IndMor2 & .84 \\
\hline & iliu. Niotal rets. & .00 & .02 & . 05 & IndMor3 & .83 \\
\hline & & & & & IndMor4 & .65 \\
\hline & & & & & BalPro1 & .69 \\
\hline & Balanced Processing & .84 & .78 & .65 & BalPro2 & .82 \\
\hline & & & & & BalPro3 & .88 \\
\hline & Self-Awareness & .91 & .88 & .72 & SelAwa1 & .84 \\
\hline
\end{tabular}




\begin{tabular}{|c|c|c|c|c|c|c|}
\hline & & & & & $\begin{array}{l}\text { SelAwa2 } \\
\text { SelAwa3 } \\
\text { SelAwa4 }\end{array}$ & $\begin{array}{l}.84 \\
.87 \\
.84\end{array}$ \\
\hline \multirow{8}{*}{$\mathrm{CB}$} & \multirow{8}{*}{ (none) } & \multirow{8}{*}{.90} & \multirow{8}{*}{.81} & \multirow{8}{*}{.82} & CreBeh1 & .65 \\
\hline & & & & & CreBeh2 & .70 \\
\hline & & & & & CreBeh3 & .72 \\
\hline & & & & & CreBeh4 & .71 \\
\hline & & & & & CreBeh5 & .71 \\
\hline & & & & & CreBeh6 & .72 \\
\hline & & & & & CreBeh7 & .69 \\
\hline & & & & & CreBeh8 & .79 \\
\hline
\end{tabular}

Note. SL: Servant Leadership; TL: Transformational Leadership; AL: Authentic Leadership; CB: Creative Behavior; CR: Composite Reliability;

AVE: Average Variance Extracted

As presented in Table 1, the loadings of all the items onto their latent constructs were between .65 and .94, except for Cha1 item in Charisma, which was deleted because its item loading was less than .60 on its latent variable (Field, 2018). Table 1 also indicates that the internal consistency and the composite reliability (CR) scores are obviously above the threshold value of .70 (Sarstedt et al., 2014). We also performed the validity of the measurement model using Average Variance Extracted (AVE) (Afsar et al., 2019). The AVE values were between .58 and .82, which are well above the cut-off value of .50 (Fornell \& Larcker, 1981). Thus, all latent variables could explain more than half of their own items' variance and guarantee adequate convergent validity.

We also calculate the AVE square root to get the discriminant validity. As presented in Table 2 , the AVE square root value for each latent variable was greater than its correlation with the other latent variables.

Table 2

AVE Square Root and Correlations

\begin{tabular}{|c|c|c|c|c|c|c|c|c|c|c|c|c|c|c|c|}
\hline 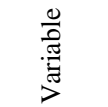 & שூ & $\sum_{\substack{0 \\
:}}^{\overrightarrow{0}}$ & $\begin{array}{l}: \overrightarrow{\tilde{E}} \\
\stackrel{0}{\Xi}\end{array}$ & $\underset{\Xi}{0}$ & 壱 & $\begin{array}{l}\mathscr{\mathscr { I }} \\
\ddot{\varpi} \\
\tilde{w}\end{array}$ & 荌 & 官 & $\overline{0}$ & $\stackrel{\Xi}{\Xi}$ & $\frac{\mathscr{\Xi}}{\mathscr{Q}}$ & $\sum_{\text {音 }}^{\vec{t}}$ & 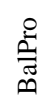 & 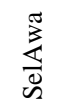 & ? \\
\hline Cha & .82 & & & & & & & & & & & & & & \\
\hline InsMot & .78 & .85 & & & & & & & & & & & & & \\
\hline IntSti & .77 & .75 & .90 & & & & & & & & & & & & \\
\hline IndCon & .76 & .67 & .70 & .88 & & & & & & & & & & & \\
\hline Emp & .79 & .71 & .73 & .73 & .82 & & & & & & & & & & \\
\hline StaBac & .77 & .64 & .66 & .66 & .74 & .85 & & & & & & & & & \\
\hline Acc & .26 & .26 & .25 & .20 & .30 & .26 & .82 & & & & & & & & \\
\hline For & .30 & .27 & .27 & .29 & .29 & .32 & -.14 & .76 & & & & & & & \\
\hline Cou & .60 & .53 & .52 & .48 & .56 & .53 & .19 & .16 & .90 & & & & & & \\
\hline Hum & .78 & .68 & .71 & .68 & .72 & .71 & .26 & .30 & .57 & .85 & & & & & \\
\hline RelTra & .79 & .72 & .74 & .71 & .73 & .68 & .24 & .31 & .56 & .75 & .81 & & & & \\
\hline IntMor & .78 & .69 & .69 & .69 & .69 & .66 & .27 & .28 & .54 & .71 & .80 & .80 & & & \\
\hline BalPro & .74 & .69 & .74 & .68 & .69 & .62 & .25 & .27 & .50 & .72 & .76 & .72 & .80 & & \\
\hline SelAwa & .78 & .71 & .72 & .71 & .71 & .66 & .29 & .26 & .49 & .71 & .76 & .74 & .77 & .85 & \\
\hline $\mathrm{CB}$ & .27 & .26 & .20 & .26 & .23 & .22 & .11 & .15 & .18 & .21 & .22 & .22 & .24 & .26 & .90 \\
\hline
\end{tabular}

This demonstrates a good deal of discriminant validity. Overall, the tables and figures above provide evidence that the measurement model is reliable and valid. Therefore, it can be concluded that all latent first-order constructs are appropriate for further analysis (Elrehail et al., 2018). 
Next, we examined both the reliability and validity of the second-order latent constructs (Wetzels et al., 2009). Cause the second-order latent variables in this study are reflective constructs, the researchers examined the loadings of each first-order on its second-order latent construct (Elrehail et al., 2018). As demonstrated in Table 3, the loadings of all first-order constructs vary between .33 and .96, and the values of Cronbach's alpha and composite reliability (CR) of second-order constructs are all above .70. Finally, the values of AVE range between .51 and .86 , which are well above the threshold value of .50. Consequently, all secondorder latent constructs in the models are reliable and valid. Now, we can move forward to test the proposed hypotheses.

Table 3

Hierarchical Measurement Model Assessment

\begin{tabular}{|c|c|c|c|c|c|}
\hline 2nd-order construct & Cronbach's alpha & $\mathrm{CR}$ & AVE & 1st-order construct & Loading \\
\hline \multirow{4}{*}{$\mathrm{TL}$} & \multirow{4}{*}{.92} & \multirow{4}{*}{.93} & \multirow{4}{*}{.80} & Charisma & .95 \\
\hline & & & & Ins. Motivation & .89 \\
\hline & & & & Int. Stimulation & .88 \\
\hline & & & & Ind. Consideration & .84 \\
\hline \multirow{6}{*}{ SL } & \multirow{6}{*}{.79} & \multirow{6}{*}{.77} & \multirow{6}{*}{.51} & Empowerment & .88 \\
\hline & & & & Standing Back & .91 \\
\hline & & & & Accountability & .33 \\
\hline & & & & Forgiveness & .37 \\
\hline & & & & Couragement & .68 \\
\hline & & & & Humility & .87 \\
\hline \multirow{4}{*}{$\mathrm{AL}$} & \multirow{4}{*}{.92} & \multirow{4}{*}{.95} & \multirow{4}{*}{.86} & Rel. Transparency & .96 \\
\hline & & & & Int. Moral Pers. & .93 \\
\hline & & & & Balanced Processing & .91 \\
\hline & & & & Self-Awareness & .89 \\
\hline
\end{tabular}

Note. TL: Transformational Leadership, SL: Servant Leadership; AL: Authentic Leadership; CR: Composite Reliability; AVE: Average

Variance Extracted

\section{Findings}

We designed two models (Figure 1 and Figure 2), including the main and the interaction effect, to support our hypotheses. Both models were established to examine and test all hypotheses using Process Macro. The estimates and interaction effects of both models are shown in Table 4 and 5. Table 4 shows that the relationship between SL and creative behavior was positive and significant $(\beta=.13 ; p<.01)$, indicating that as the SL increases, creative behavior will increase too. Accordingly, the authors decided to support Hypothesis 1 . Table 4 also shows that the interaction "SL $\times \mathrm{AL}$ " has a significant effect $(\beta=.14 ; p<.01)$, indicating that AL has a positive moderating effect on the role of SL. As a result, the authors decided to support Hypothesis 3. This shows that SL is more effective on creative behavior where AL is more visible on SL.

Table 4

SL Predicted CB Moderator AL

\begin{tabular}{lcccc}
\hline Variable name & $\beta$ & $S E$ & $t$ & $p$ \\
\hline constant & 3.86 & .02 & 167.54 & $.00^{* * *}$ \\
SL & 0.13 & .05 & 2.66 & $.00^{* *}$ \\
AL & 0.14 & .04 & 3.24 & $.00^{* *}$ \\
SL $x$ AL & 0.14 & .02 & 5.57 & $.00^{* *}$ \\
\hline Note. $\mathrm{p}^{*} .05 * * \mathrm{p}<.01$ & & &
\end{tabular}

Regarding the role of TL on creative behavior, the relationship between TL and creative behavior was also positive and significant $(\beta=.16 ; p<.01)$, indicating that TL has a positive effect on creative behavior, thereby the researchers decided to support Hypothesis 2 (Table 5). 
The result also shows that the interaction "TL $\times$ AL" has a significant effect $(\beta=.133 ; p<.01)$, indicating that AL has a positive moderating effect on the role of TL (Table 5). This shows that TL is more effective on creative behavior when AL prevails on TL. Thus, the researchers decided to support Hypothesis 4.

Table 5

TL Predicted CB Moderator $A L$

\begin{tabular}{lcccc}
\hline Variable name & $\beta$ & $S E$ & $t$ & $p$ \\
\hline constant & 3.85 & .02 & 164.49 & $.0^{* *}$ \\
TL & 0.16 & .04 & 3.40 & $.00^{* *}$ \\
AL & 0.09 & .05 & 1.77 & .07 \\
TL x AL & 0.13 & .02 & 6.04 & $.00^{* *}$ \\
\hline Note. $* p<.05 * *<.01$ & & &
\end{tabular}

Table 6 and Figure 3 show the relationship between SL and creative behavior under high, average, and low levels of AL. This result means that, with respect to the average and high level of AL and SL, SL coupled with AL exerts joint positive effects on creative behavior. In conclusion, the stronger the AL, the better the SL predicted creative behavior.

Table 6

Conditional Effects of SL at the Values of the Moderator

\begin{tabular}{lcccc}
\hline Values of AL & Effect & $S E$ & $t$ & \\
\hline mean-1sd & .01 & .05 & .23 & .81 \\
mean & .13 & .05 & 2.66 & $.00^{* *}$ \\
mean+1sd & .25 & .05 & 4.59 & $.00^{* *}$ \\
\hline
\end{tabular}

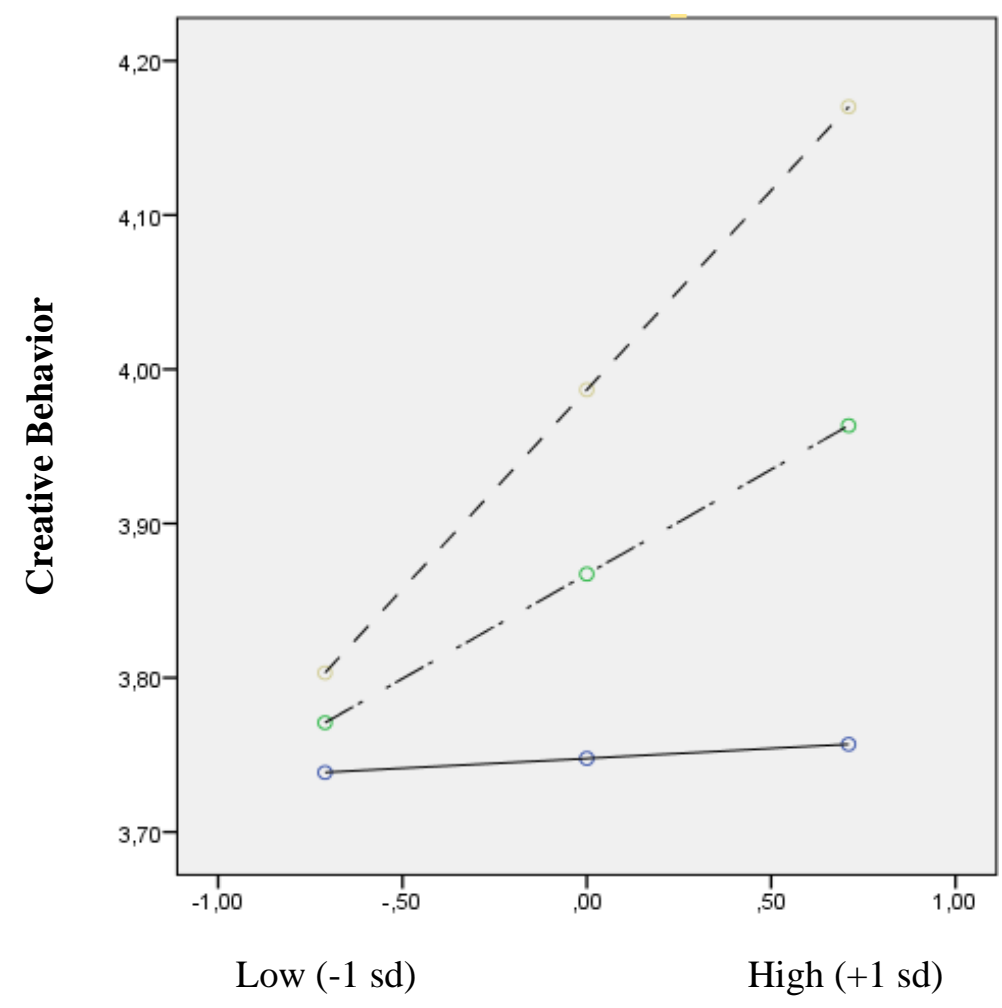

Servant Leadership

Figure 3. Interaction plot 1

Table 7 and Figure 4 indicates the relationship between TL and creative behavior under high, average, and low levels of AL. This result means that, with respect to the average and high level of AL and TL, TL coupled with AL exerts joint positive effects on creative behavior. This 
indicated that TL was more predictive of creative behavior as AL became stronger. Therefore, we can conclude the claim that AL has a positive moderating effect on SL and TL.

Table 7

Conditional Effects of TL at Values of the Moderator

\begin{tabular}{lcccc}
\hline Values of AL & Effect & $S E$ & $t$ & $p$ \\
\hline mean-1sd & .05 & .05 & 1.11 & .26 \\
mean & .16 & .04 & 3.40 & $.00^{* *}$ \\
mean+1sd & .27 & .05 & 5.21 & $.00^{* *}$ \\
\hline
\end{tabular}

Note. $* \mathrm{p}<.05 * * \mathrm{p}<.01$

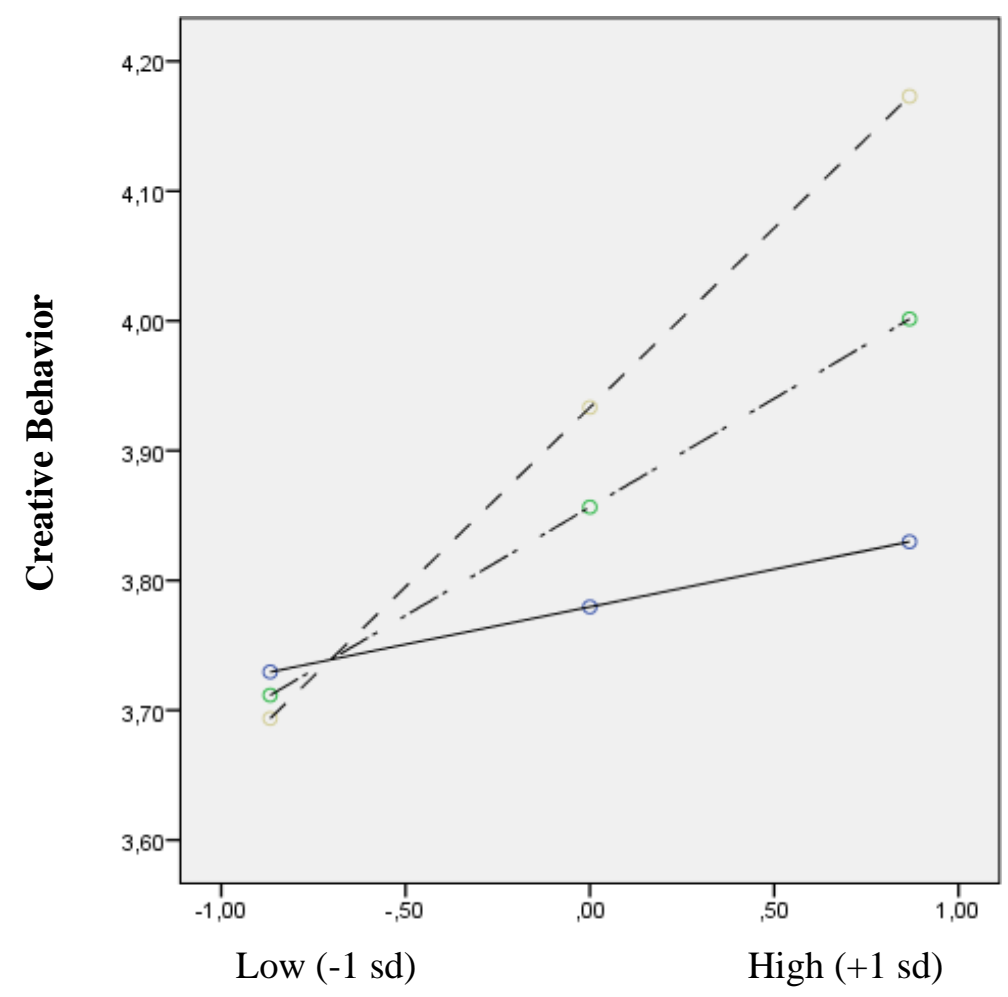

Transformational Leadership

Figure 4. Interaction plot 2

In summary, our results indicate that Servant and Transformational Leadership have positive direct effects on creative behavior. Moreover, when AL interacts significantly with TL and SL with respect to the average and high level of AL, SL and TL effects on creative behavior increase. Finally, we conclude that all Hypotheses proposed were supported.

\section{Discussion}

First, our study aims to understand the direct impact of SL and TL on creative behavior. Second, since there are few studies in the literature on whether SL and TL need another leadership type to increase creative behavior, our study aims to examine the moderator role of AL in these relationships. Third, authenticity is not the main focus of SL and TL, but authenticity emerges as an important trait that every leader should embellish because this concept is closely related to ethics and morality.

SL emerges as an important type of leadership in many cultures and is very important for creativity (Neubert et al., 2008). Experimental studies show that SL has a positive effect on 
work attitudes, organizational citizenship behaviors, performance, and creativity (Ehrhart, 2004; Harrington et al., 2017; Hunter et al., 2013; van Dierendonck, 2011; Walumbwa et al., 2010). When leaders are servants, employees become more prone to mutual support and concern for others, providing psychological trust (Liden et al., 2015). For this reason, employees take risks to use creative methods, which is a beneficial action to increase employee creativity (Yoshida et al., 2014). Our findings are similar to other studies in this respect and support that SL has a direct positive effect on creative behavior, as Shin and Zhou in their research (2003) stated. The fact that SL is always employee-oriented also meets the socioemotional needs of the employees and provides meaningful support in producing creative ideas and behaviors.

The results also support the moderator effect of AL between the relationship of SL and creative behavior. The effect of SL on creative behavior increases significantly as the level of AL increases and decreases significantly as it decreases. The main effect of SL on creative behavior emerges when SL begins to exhibit AL; otherwise, this effect is limited. In this case, the strengthening role of AL should definitely be taken into account. Therefore, this study can also be presented as empirical evidence to demonstrate the moderator role of AL in the relationship between SL and creative behavior.

TL has been studied more frequently by researchers lately (Kearney \& Gebert, 2009), and this concept has been proved to be effective in raising the performance and personal values of followers (Bass, 1985; Jung, 2001). The relationship between TL and creativity was also studied frequently but not as much as TL (Gumusluoglu \& Ilsev; 2009; Shin \& Zhou, 2003). TL affects employee creativity in two ways: cognitive and motivational (Kearney \& Gebert, 2009). TL influences this type of creativity at a cognitive level by providing intellectual stimulation (Waldman \& Bass, 1991), offering different perspectives, and trying to change the status quo (Bass, 1985). TL plays the role of creating vision at the motivational level, considering followers individually, and revealing passions (Conger \& Kanungo, 1998; Shamir, House, \& Arthur, 1993). In our findings, the effect of TL on creative behavior was also examined. Not surprisingly, the results obtained from the analysis determine that TL has a positive effect on creative behavior, just as it does with SL (Alzawahreh, 2011; Vaccaro et al., 2012). These findings are also supported by Gong, Huang, and Farh (2009). TL's individual consideration to employees also meets their socio-emotional needs and provides meaningful support for producing creative ideas and behaviors.

As the effect of AL increases, the effect of TL on creative behavior increases, and as the effect of AL decreases, the effect of TL on creative behavior decreases. This is because the leader creates a safer, more friendly, and less risky environment for employees. In this case, it is understood that AL has a moderating role in the relationship, and the main effect of TL on creative behavior is even greater when TL starts to exhibit AL. Therefore, this study can also be presented as empirical evidence to demonstrate the moderator role of AL in the relationship between TL and creative behavior.

\section{Conclusion}

Our findings state that employee creative behavior in organizations increases even more, especially with servant and transformational leaders armed with authentic leadership traits. AL strengthens the relationship of the other two leaderships with creative behavior and creates a 
more conducive environment for creativity. The followers also feel like an honest, selfconfident and transparent leader, making it easier for them to take risks and generate and implement new ideas. In terms of theoretical and practical implications, people who think of as future leaders in the organization should be trained based on SL or TL, and these leaders should also be taught the concept of AL. AL within the organization is also important to increase the effect of SL or TL on creative behavior and create a positive psychological and ethical climate based on this (Schaubroeck et al., 2011).

\section{Theoretical and Practical Implementations}

First, while previous research narrows effective leadership styles to Transformational and Transactional Leadership, neglecting new approaches to leadership (Elrehail et al., 2018), this study theorized the impact of TL, SL, and even AL on creativity and creative behavior in the private sector. Second, this study conducted in a developing country shows significant similarities with studies conducted in the western context. This will force Turkey's leadership and cultural structure to be similar to western culture in creativity and creative behavior. In this context, it will further develop creativity and creative behavior through leadership. Third, previous research has taken into account the role that only a single leadership rules in organizations and hypothesized that creativity and creative behavior increase in this way. Investigation of the moderator role of another type of leadership, here AL, in this relationship sheds light on some of the circumstances in facilitating the role that leadership plays in promoting more creative behavior in organizations. Our findings highlight that AL offers more opportunities to get opinions, suggestions, ideas from employees when they moderate the creative processes of the other leaderships (Edmondson, 1999; Elrehail et al., 2018). Fourth, when AL plays a dominant role over SL or TL, leaders are more supportive of creative behaviors, and employees can achieve the best results in problem-solving and generating new ideas due to the psychological and ethical surroundings organized by AL (Laschinger et al., 2001; Lemoine et al., 2019). This study offers many recommendations for leaders in the Turkish private sector in terms of creative behavior. First, while SL and TL provide an environment that supports creative behavior in the private sector, these leaders show and focus on AL foster an organizational climate that increases creativity and creative behavior among the working staff.

\section{Limitations and Future Research}

This study has a couple of limitations as follows: In this cross-sectional study, the results might yield spurious causality, but Ajzen's (1991) Theory of Planned Behavior suggests that causality progresses from perceptions to attitudes and from attitudes to behaviors, so the causal direction proposed is valid for both models. It is recommended that researchers conduct longitudinal studies in future studies. This study was performed in private companies located in Western Turkey, which narrows our ability to generalize the findings. Future studies should investigate other public-state companies in other regions as well. Furthermore, the study was conducted in a developing country like Turkey. Future studies should examine these models in developed countries. Finally, the study focused on two leadership styles separately, but other leadership styles are also available. Thus, future studies should investigate the relationship between other leadership styles and creative behavior. Moreover, researchers may take other leaderships as moderators. Adding other moderating leadership such as paternalistic and delegative leadership will be quite beneficial. 


\section{References}

Afsar, B., Masood, M., \& Umrani, W. A. (2019). The role of job crafting and knowledge sharing on the effect of transformational leadership on innovative work behavior. Personnel Review, 48(5), 1186-1208.

Ajzen, I. (1991). The theory of planned behavior. Organizational Behavior and Human Decision Processes, 50(2), $179-211$.

Alzawahreh, A. A. (2011). Transformational leadership of superiors and creativity level among faculty members in Jordanian universities. Journal of Institutional Research Southeast Asia, 9(1), 125-132.

Amabile, T. M. (1983). The social psychology of creativity: A componential conceptualization. Journal of Personality and Social Psychology, 45(2), 357.

Amabile, T. M. (1988). A model of creativity and innovation in organizations. Research in Organizational Behavior, 10(1), $123-167$.

Amabile, T. M. (1997). Motivating creativity in organizations: On doing what you love and loving what you do. California Management Review, 40(1), 39-58.

Amabile, T. M., Barsade, S. G., Mueller, J. S., \& Staw, B. M. (2005). Affect and creativity at work. Administrative Science Quarterly, 50(3), 367-403.

Amabile, T. M., \& Conti, R. (1999). Changes in the work environment for creativity during downsizing. Academy of Management Journal, 42(6), 630-640.

Amabile, T. M., Conti, R., Coon, H., Lazenby, J., \& Herron, M. (1996). Assessing the work environment for creativity. Academy of Management Journal, 39(5), 1154-1184.

Amabile, T. M., \& Gryskiewicz, N. D. (1989). The creative environment scales: Work environment inventory. Creativity Research Journal, 2(4), 231-253.

Amabile, T. M., Schatzel, E. A., Moneta, G. B., \& Kramer, S. J. (2004). Leader behaviors and the work environment for creativity: Perceived leader support. The Leadership Quarterly, 15(1), 5-32.

Anderson, N., De Dreu, C. K., \& Nijstad, B. A. (2004). The routinization of innovation research: A constructively critical review of the state-of-the-science. Journal of Organizational Behavior, 25(2), 147-173.

Arda, Ö. A., Aslan, T., \& Alpkan, L. (2016). Review of practical implications in authentic leadership studies. ProcediaSocial and Behavioral Sciences, 229, 246-252.

Artz, K. W., Norman, P. M., Hatfield, D. E., \& Cardinal, L. B. (2010). A longitudinal study of the impact of R\&D, patents, and product innovation on firm performance. Journal of Product Innovation Management, 27(5), 725-740.

Avolio, B. J., \& Bass, B. M. (1995). Individual consideration viewed at multiple levels of analysis: A multi-level framework for examining the diffusion of transformational leadership. The Leadership Quarterly, 6(2), 199-218.

Avolio, B. J., \& Bass, B. M. (2004). Multifactor leadership questionnaire (TM). Mind Garden, Inc. Menlo Park, CA.

Avolio, B. J., Bass, B. M., \& Jung, D. I. (1999). Re-examining the components of transformational and transactional leadership using the Multifactor Leadership. Journal of Occupational and Organizational Psychology, 72(4), 441-462.

Avolio, B. J., \& Gardner, W. L. (2005). Authentic leadership development: Getting to the root of positive forms of leadership. The Leadership Quarterly, 16(3), 315-338.

Bain, P. G., Mann, L., \& Pirola-Merlo, A. (2001). The innovation imperative: The relationships between team climate, innovation, and performance in research and development teams. Small Group Research, 32(1), 55-73.

Bandura, A. (2001). Social cognitive theory: An agentic perspective. Annual Review of Psychology, 52(1), 1-26.

Bass, B. M. (1985). Leadership: Good, better, best. Organizational Dynamics, 13(3), 26-40.

Bass, B. M., \& Avolio, B. J. (1990). Developing transformational leadership: 1992 and beyond. Journal of European Industrial Training, 14(5).

Bass, B. M., \& Avolio, B. J. (1994). Transformational leadership and organizational culture. The International Journal of Public Administration, 17(3-4), 541-554.

Bass, B. M., \& Riggio, R. E. (2005). Transformational Leadership (2nd ed.). Psychology Press.

Blau, P. M. (1964). Justice in Social exchange. Sociological Inquiry, 34(2), 193-206.

Bobbio, A., Dierendonck, D. V., \& Manganelli, A. M. (2012). Servant leadership in Italy and its relation to organizational variables. Leadership, 8(3), 229-243.

Bono, J. E., \& Judge, T. A. (2004). Personality and transformational and transactional leadership: a meta-analysis. Journal of Applied Psychology, 89(5), 901.

Bullinger, H. J., Auernhammer, K., \& Gomeringer, A. (2004). Managing innovation networks in the knowledge-driven economy. International Journal of Production Research, 42(17), 3337-3353. 
Burningham, C., \& West, M. A. (1995). Individual, climate, and group interaction processes as predictors of work team innovation. Small Group Research, 26(1), 106-117.

Burns, J. M. (1978) Leadership by James MacGregor Burns (1st ed.). Harper \& Row.

Chiniara, M., \& Bentein, K. (2016). Linking servant leadership to individual performance: Differentiating the mediating role of autonomy, competence and relatedness need satisfaction. The Leadership Quarterly, 27(1), 124-141.

Conger, J. A., \& Kanungo, R. N. (1998). The empowerment process: Integrating theory and practice. Academy of Management Review, 13(3), 471-482.

Çömez, P., Erdil, O., Alpkan, L., \& Kitapçı, H. (2011). The effects of ambidexterity and generative learning on innovative firm performance: the mediating effect of transformational leadership. Journal of Global Strategic Management, 2(5), 7689.

Damanpour, F. (1996). Organizational complexity and innovation: developing and testing multiple contingency models. Management Science, 42(5), 693-716.

Dongil (Don) Jung, \& Sosik, J. J. (2006). Who are the spellbinders? Identifying personal attributes of charismatic leaders. Journal of Leadership \& Organizational Studies, 12(4), 12-26.

Edmondson, A. (1999). Psychological safety and learning behavior in work teams. Administrative Science Quarterly, 44(2), $350-383$.

Ehrhart, M. G. (2004). Leadership and procedural justice climate as antecedents of unit-level organizational citizenship behavior. Personnel Psychology, 57(1), 61-94.

Elrehail, H., Emeagwali, O. L., Alsaad, A., \& Alzghoul, A. (2018). The impact of Transformational and Authentic leadership on innovation in higher education: The contingent role of knowledge sharing. Telematics and Informatics, 35(1), 55-67.

Erickson, R. J. (1995). The importance of authenticity for self and society. Symbolic Interaction, 18(2), 121-144.

Eva, N., Robin, M., Sendjaya, S., Van Dierendonck, D., \& Liden, R. C. (2019). Servant leadership: A systematic review and call for future research. The Leadership Quarterly, 30(1), 111-132.

Field, A. (2018). Discovering statistics using IBM SPSS Statistics (5th ed.). SAGE Publications Ltd.

Fishbein, M., \& Ajzen, I. (2005). Theory-based behavior change interventions: Comments on Hobbis and Sutton. Journal of Health Psychology, 10(1), 27-31.

Fornell, C., \& Larcker, D. F. (1981). Structural Equation Models with Unobservable Variables and Measurement Error: Algebra and Statistics. Journal of Marketing Research, 18(3), 382.

Fredrickson, B. L. (2001). The role of positive emotions in positive psychology: The broaden-and-build theory of positive emotions. American Psychologist, 56(3), 218.

Gardner, W. L., Avolio, B. J., Luthans, F., May, D. R., \& Walumbwa, F. (2005). “Can you see the real me?” A self-based model of authentic leader and follower development. The Leadership Quarterly, 16(3), 343-372.

George, J. M., \& Zhou, J. (2001). When openness to experience and conscientiousness are related to creative behavior: an interactional approach. Journal of Applied Psychology, 86(3), 513.

Giallonardo, L. M., Wong, C. A., \& Iwasiw, C. L. (2010). Authentic leadership of preceptors: predictor of new graduate nurses' work engagement and job satisfaction. Journal of Nursing Management, 18(8), 993-1003.

Gong, Y., Huang, J. C., \& Farh, J. L. (2009). Employee learning orientation, transformational leadership, and employee creativity: The mediating role of employee creative self-efficacy. Academy of Management Journal, 52(4), 765-778.

Gonzalez, S. T., López, M. C. N., Marcos, Y. Q., \& Rodríguez-Marín, J. (2012). Development and validation of the theory of planned behavior questionnaire in physical activity. The Spanish Journal of Psychology, 15(2), 801-816.

Greenleaf, R. K. (2008). Servant as leader. The Greenleaf Center for Servant Leadership: Westfield, In.

Gumusluoglu, L., \& Ilsev, A. (2009). Transformational leadership, creativity, and organizational innovation. Journal of Business Research, 62(4), 461-473.

Hannah, S. T., Avolio, B. J., \& Walumbwa, F. O. (2011). Relationships between authentic leadership, moral courage, and ethical and pro-social behaviors. Business Ethics Quarterly, 21(4), 555-578.

Harrington, D. M., \& Chin-Newman, C. S. (2017). Conscious motivations of adolescent visual artists and creative writers: Similarities and differences. Creativity Research Journal, 29(4), 442-451.

Hayes, A. F. (2018). Partial, conditional, and moderated moderated mediation: Quantification, inference, and interpretation. Communication Monographs, 85(1), 4-40.

Howell, J. M., \& Higgins, C. A. (1990). Champions of technological innovation. Administrative Science Quarterly, $317-341$.

Hunter, D. E., \& Nielsen, S. B. (2013). Performance management and evaluation: Exploring complementarities. New Directions for Evaluation, 2013(137), 7-17. 
Jaramillo, F., Grisaffe, D. B., Chonko, L. B., \& Roberts, J. A. (2009). Examining the impact of servant leadership on salesperson's turnover intention. Journal of Personal Selling and Sales Management, 29(4), 351-365.

Jung, D. I. (2001). Transformational and transactional leadership and their effects on creativity in groups. Creativity Research Journal, 13(2), 185-195.

Jung, D. I., Chow, C., \& Wu, A. (2003). The role of transformational leadership in enhancing organizational innovation: Hypotheses and some preliminary findings. The Leadership Quarterly, 14(4-5), 525-544.

Ilies, R., Morgeson, F. P., \& Nahrgang, J. D. (2005). Authentic leadership and eudaemonic well-being: Understanding leaderfollower outcomes. The Leadership Quarterly, 16(3), 373-394.

Kearney, E., \& Gebert, D. (2009). Managing diversity and enhancing team outcomes: the promise of transformational leadership. Journal of Applied Psychology, 94(1), 77.

Kernis, M. H., \& Goldman, B. M. (2006). A multicomponent conceptualization of authenticity: Theory and research. Advances in Experimental Social Psychology, 38, 283-357.

Laschinger, H. K. S., Wong, C. A., \& Grau, A. L. (2013). Authentic leadership, empowerment and burnout: a comparison in new graduates and experienced nurses. Journal of Nursing Management, 21(3), 541-552.

Laub, J. A. (1999). Assessing the servant organization: Development of the servant organizational leadership assessment (SOLA) instrument. Dissertation Abstracts International, 60(02).

Lemoine, G. J., Hartnell, C. A., \& Leroy, H. (2019). Taking stock of moral approaches to leadership: An integrative review of ethical, authentic, and servant leadership. Academy of Management Annals, 13(1), 148-187.

Leys, C., Klein, O., Dominicy, Y., \& Ley, C. (2018). Detecting multivariate outliers: Use a robust variant of the Mahalanobis distance. Journal of Experimental Social Psychology, 74, 150-156.

Liden, R. C., Wayne, S. J., Liao, C., \& Meuser, J. D. (2014). Servant leadership and serving culture: Influence on individual and unit performance. Academy of Management Journal, 57(5), 1434-1452.

Liden, R. C., Wayne, S. J., Meuser, J. D., Hu, J., Wu, J., \& Liao, C. (2015). Servant leadership: Validation of a short form of the SL-28. The Leadership Quarterly, 26(2), 254-269.

Mearns, K. J., \& Reader, T. (2008). Organizational support and safety outcomes: An un-investigated relationship? Safety Science, 46(3), 388-397.

Neff, K.D., \& Harter, S. (2002). The Role of Power and Authenticity in Relationship Styles Emphasizing Autonomy, Connectedness, or Mutuality among Adult Couples. Journal of Social and Personel Relationships, 19(6), 835-857.

Neubert, M. J., Hunter, E. M., \& Tolentino, R. C. (2016). A servant leader and their stakeholders: When does organizational structure enhance a leader's influence? The Leadership Quarterly, 27(6), 896-910.

Neubert, M. J., Kacmar, K. M., Carlson, D. S., Chonko, L. B., \& Roberts, J. A. (2008). Regulatory focus as a mediator of the influence of initiating structure and servant leadership on employee behavior. Journal of Applied Psychology, 93(6), 1220.

Piccolo, R. F., \& Colquitt, J. A. (2006). Transformational leadership and job behaviors: The mediating role of core job characteristics. Academy of Management Journal, 49(2), 327-340.

Pillai, R., \& Williams, E. A. (2004). Transformational leadership, self-efficacy, group cohesiveness, commitment, and performance. Journal of Organizational Change Management, 17(2), 144-159.

Prati, L. M., Douglas, C., Ferris, G. R., Ammeter, A. P., \& Buckley, M. R. (2003). Emotional intelligence, leadership effectiveness, and team outcomes. The International Journal of Organizational Analysis, 11(1), 21-40.

Rickards, T., Chen, M. H., \& Moger, S. (2001). Development of a self-report instrument for exploring team factor, leadership and performance relationships. British Journal of Management, 12(3), 243-250.

Rosenthal, S. (2018). Procedural information and behavioral control: Longitudinal analysis of the intention-behavior gap in the context of recycling. Recycling, 3(1), 5 .

Russell, R. F., \& Stone, A. G. (2002). A review of servant leadership attributes: Developing a practical model. Leadership and Organization Development Journal, 23(3), 145-157.

Saks, A. M. (2006). Antecedents and consequences of employee engagement. Journal of Managerial Psychology, 21(7), 600-619

Sarstedt, M., Ringle, C. M., Smith, D., Reams, R., \& Hair Jr, J. F. (2014). Partial least squares structural equation modeling (PLS-SEM): A useful tool for family business researchers. Journal of Family Business Strategy, 5(1), 105-115.

Schaubroeck, J., Lam, S. S., \& Peng, A. C. (2011). Cognition-based and affect-based trust as mediators of leader behavior influences on team performance. Journal of Applied Psychology, 96(4), 863.

Scott, S. G., \& Bruce, R. A. (1994). Determinants of innovative behavior: A path model of individual innovation in the workplace. Academy of Management Journal, 37(3), 580-607. 
Sendjaya, S., \& Pekerti, A. (2010). Servant leadership as antecedent of trust in organizations. Leadership \& Organization Development Journal, 31(7), 643-663.

Sendjaya, S., Sarros, J. C., \& Santora, J. C. (2008). Defining and measuring servant leadership behaviour in organizations. Journal of Management Studies, 45(2), 402-424.

Shamir, B., \& Eilam, G. (2005). "What's your story?” A life-stories approach to authentic leadership development. The Leadership Quarterly, 16(3), 395-417.

Shamir, B., House, R. J., \& Arthur, M. B. (1993). The motivational effects of charismatic leadership: A self-concept based theory. Organization Science, 4(4), 577-594.

Shin, S. J., \& Zhou, J. (2003). Transformational leadership, conservation, and creativity: Evidence from Korea. Academy of Management Journal, 46(6), 703-714.

Simons, T. (2002). Behavioral integrity: The perceived alignment between managers' words and deeds as a research focus. Organization Science, 13(1), 18-35.

Spector, P. E. (2006). Industrial and organizational psychology - research and practice (4th ed.). New York: John Wiley \& Sons Inc.

Tabachnick, B. G., \& Fidell, L. S. (2013). Using multivariate statistics (7th ed.). California: Pearson.

Tierney, P., Farmer, S. M., \& Graen, G. B. (1999). An examination of leadership and employee creativity: The relevance of traits and relationships. Personnel Psychology, 52(3), 591-620.

Torrance, E. P. (1993). Understanding creativity: Where to start? Psychological Inquiry, 4(3), $232-234$.

Unsworth, K. (2001). Unpacking creativity. Academy of Management Review, 26(2), 289-297.

Vaccaro, I. G., Jansen, J. J., Van Den Bosch, F. A., \& Volberda, H. W. (2012). Management innovation and leadership: The moderating role of organizational size. Journal of Management Studies, 49(1), $28-51$.

Van Dierendonck, D., \& Nuijten, I. (2011). The servant leadership survey: Development and validation of a multidimensional measure. Journal of Business and Psychology, 26(3), 249-267.

Waldman, D. A., \& Bass, B. M. (1991). Transformational leadership at different phases of the innovation process. The Journal of High Technology Management Research, 2(2), 169-180.

Walumbwa, F. O., Avolio, B. J., Gardner, W. L., Wernsing, T. S., \& Peterson, S. J. (2008). Authentic leadership: Development and validation of a theory-based measure. Journal of Management, 34(1), 89-126.

Walumbwa, F. O., Hartnell, C. A., \& Oke, A. (2010). Servant leadership, procedural justice climate, service climate, employee attitudes, and organizational citizenship behavior: a cross-level investigation. Journal of Applied Psychology, 95(3), 517.

Wetzels, M., Odekerken-Schröder, G., \& Van Oppen, C. (2009). Using PLS Path Modeling for assessing hierarchical construct models: Guidelines and empirical illustration. MIS Quarterly, 33(1), 177-195.

Wong, P. T., \& Page, D. (2003b). Servant leadership: An opponent-process model and the revised servant leadership profile. Proceedings of the Servant Leadership Research Roundtable (pp. 1-11).

Woodman, R. W., Sawyer, J. E., \& Griffin, R. W. (1993). Toward a theory of organizational creativity. Academy of Management Review, 18(2), 293-321.

Yang, J., Liu, H., \& Gu, J. (2017). A multi-level study of servant leadership on creativity: The roles of self-efficacy and power distance. Leadership \& Organization Development Journal, 38(5), 610-629.

Yoshida, D. T., Sendjaya, S., Hirst, G., \& Cooper, B. (2014). Does servant leadership foster creativity and innovation? A multi-level mediation study of identification and prototypicality. Journal of Business Research, 67(7), 1395-1404.

Zhou, J., \& George, J. M. (2003). Awakening employee creativity: The role of leader emotional intelligence. The Leadership Quarterly, 14(4-5), 545-568.

Zhou, J., \& Shalley, C. E. (2011). Deepening our understanding of creativity in the workplace: A review of different approaches to creativity research. APA handbook of Industrial and Organizational psychology, Vol 1: Building and Developing the Organization, 275-302.

Zhu, W., Avolio, B. J., Riggio, R. E., \& Sosik, J. J. (2011). The effect of authentic transformational leadership on follower and group ethics. The Leadership Quarterly, 22(5), 801-817.

Zou, W. C., Tian, Q., \& Liu, J. (2015). Servant leadership, social exchange relationships, and follower's helping behavior: Positive reciprocity belief matters. International Journal of Hospitality Management, 51, 147-156. 


\section{Acknowledgements}

Not applicable.

\section{Disclosure Statement}

No potential conflict of interest was reported by the authors.

\section{Funding Acknowledgements}

Not applicable.

\section{Open Access}

The International Journal of Organizational Leadership publishes open access articles under the terms of the Creative Commons Attribution (CC BY) License, which permits use, distribution, and reproduction in any medium, provided the original work is properly cited. 